\title{
EAP alignment in EFL writing courses towards developing student's academic writing skills
}

\author{
Melaku Bayu Workie ${ }^{1}$, Zelealem Shitahun Haregu ${ }^{2}$ \\ 1,2 Department of English Language and Literature, Faculty of Social Sciences and Humanities, \\ Debre Tabor University, Debre Tabor, Ethiopia \\ ${ }^{1}$ melabay@dtu.edu.et (corresponding author) \\ ${ }^{2}$ zeleshi@dtu.edu.et
}

Received: December 25, 2019;

Accepted: February 22, 2020;

Published: March 20, 2020

\begin{abstract}
The objective of the present study was to assess the prevailing alignment of English for academic purposes (EAP) in EFL writing courses vis-à-vis the development of academic writing skills of students in public universities of Amhara National Regional State (ANRS) in Ethiopia. The study used a descriptive survey that involved quantitative and qualitative methods. A questionnaire, focus-group discussions, and syllabus and materials survey were used to gather primary and secondary data, respectively, for the study. The descriptive statistics were employed in analyzing the quantitative data. The qualitative data were analyzed and reported thematically. The results showed there were existed a comparable horizontal (cross-department) distribution pattern of common writing courses among the three universities; all learners in taking the common course 'Basic Writing Skills' in each university learnt with the same syllabus and material regardless of their fields of study. So, there was a poor alignment of writing courses with the target students' mainstream discipline (i.e., learning and discourse) both in terms of content and genre.
\end{abstract}

Keywords: academic writing; academic writing skills; alignment; English for academic purposes (EAP); EFL writing

How to cite this paper (in APA style): Workie, M. B., \& Haregu, Z. S. (2020). EAP alignment in EFL writing courses towards developing student's academic writing skills. Journal on English as a Foreign Language, 10(1), 120-140. https://doi.org/10.23971 ßjefl.v10i1.1736

Journal on English as a Foreign Language, 10(1), 120-140

Copyright @ 2020 by JEFL, p-ISSN 2088-1657; e-ISSN 2502-6615 
DOI: https: //doi.org/10.23971/jefl.v10i1.1736

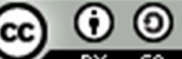

The English language is a global language which is used for communication with native and non-native speakers worldwide, in the educational sector in Ethiopia, all secondary school and university students need it for their studies in order to search for information and obtain knowledge (Workie, 2019). Language is at the heart of academic life and success. The required language skills and standards are needed so as to acquire and use them. This fundamental belief has had significant implications for language pedagogy since about the second half of the $20^{\text {th }}$ century when the retreat from pedagogical initiation in research had the effect of paradigm shift increasingly from the teacher's methods to the situation of students (Otte \& Mlynarczyk, 2010). In fact, current global trends of secondforeign language education signify that arguably the greatest concern and focus of needs analysis in curriculum development has been placed on the area and role of language for academic purposes (LAP) (Leung, 2008).

The principal concept and purpose of second/foreign language curriculum alignment, according to, essentially rest on ensuring the second language curriculum reflects the content and processes of the regular school curriculum (Richard, 2006; Yazdani, 2018). Accordingly, in contemporary EFL education, students' academic literacy problems, especially where the language is the medium of instruction, have comprehensively been dealt with alignment and provision of English for academic purposes (EAP) courses across mainstream curricula (Mol \& Tin, 2008). This practice is believed to have greater effects in EFL/ESL higher education contexts in which the students are highly expected, but likely find it difficult, to acclimate themselves into their disciplinary discourse community and the range of genres associated with such community.

The notion of academic writing is closely related to as well as can be drawn from the relationship between writing and learning as well as the role of the former in the latter. This is quite true for many reasons including the fact that, according to Puhr (2007), writing is the principal medium for generating and conveying knowledge in all fields. In principle, since writing itself is either formally learned or culturally transmitted, it demands deliberate instructional settings in which the learning process essentially involves a set of continuous practice (Brown, 2000; Myles, 2002). One of the motivations behind the teaching 
and development of academic writing, as Belcher (2009) claimed, is to help those especially lacking and in need of the language and discourse skills required for the academic contexts they are situated and hope to succeed in.

In the Ethiopian higher education context, English writing tasks have such a vital place that most content courses provided across mainstream curricula often require students to write various types or genres of academic papers such as essays, reviews, laboratory reports, proposals, research reports, and so on as part of their ongoing assessments. This, however, has been a substantial challenge for students to deliver and instructors to assess in terms of the quality of students' writing in particular and learning in general.

Several works of literature and researches on writing and writing instruction show that though writing plays a vital role in learning across mainstream curricula, the skill of writing for academic purposes has long been a tremendous challenge for practitioners, particularly in higher levels of education (Myles, 2002; Ožarska, 2008). In other words, the more academic is the writing required (especially where $\mathrm{L}_{2}$ learners are involved), the greater the chance that students' writing problems become both frequent and serious. Of note, over the last three or so decades, various problems in students' academic writing have been pointed out across different research contexts. For instance, grammatical inaccuracy and fossilization of linguistic errors (Mardijono, 2003; Myles, 2002), problems of coherence and cohesion (Kooshafar et al., 2012), lack of critically deliberated and well-supported arguments, lack of use of appropriate register and style (Ozarska, 2008), lack of use of appropriate genre, citation and referencing problems (Neville, 2007), and so on were claimed to be profound both in their frequency in and impact on the quality of students' writing.

Though a number of local studies have been conducted on different EFL writing and writing instruction issues, most of them appeared to lack specification and/or meticulousness in their respective writing purposes and framework and, most, unfortunately, did not address academic writing issues in due particularity and depth (Amogne, 2013). Perhaps worth-mentioning exceptional attempts made in this regard are the studies by Abebe (2013) and Tefera (2003) that respectively assessed academic genre knowledge of EFL learners through content and language integrated learning (CLIL), explored academic writing problems and associated factors in Bahir Dar University and investigated students' academic writing in response to instructors' expectations at Addis Ababa University. The latter researches, however, overlooked and,

Journal on English as a Foreign Language, 10(1), 120-140

Copyright (C) 2020 by JEFL, p-ISSN 2088-1657; e-ISSN 2502-6615 
therefore, failed to assess the existing groundwork for EFL writing education the curriculum. As a result, local researches remain negligent of EAP alignment and implementation in writing courses towards developing students' academic writing skills in the specific higher education context.

The ultimate premise in propositioning this study is that tertiary level students are expected to acquire considerable competence in writing their academic projects so that they can succeed throughout their academic journey and beyond. Yet students are not able to write in their academic projects. Lacking this competence, on the other hand, leads one to "losing touch with the joy of inquiry, the sense of intellectual curiosity, and the inestimable satisfaction of acquiring wisdom that are the touchstones of humanity" (Nasser, 2018; Sanu, 2016; Graham \& Hebert, 2010). The argument here is, therefore, that where this problem is faced and a due investigation is required, it is essential that educators should assess the prime foundation and policy that guides the actual teaching-learning practice, which is the curriculum in the particular academic context. This can be further drawn from the broader conception that language and language teaching problems are usually subjective to the particular social context and setting they represent (Hyland, 2016).

This study, therefore, aimed at assessing the prevailing alignment of EAP in EFL writing courses vis-à-vis the development of academic writing skills of students in public universities in Amhara National Regional State (ANRS). To this end, the study principally inquired and disclosed answers to the following major questions, "How are writing courses distributed across mainstream curricula at the target universities?", To what extent are common writing courses compatibly aligned with the disciplinary content across host departments?", and "How effectively are academic writing genres incorporated in common writing courses vis-à-vis the respective disciplinary discourse of host departments?"

This study was intended to provide detailed information and empirical insights regarding the alignment of EAP in EFL writing courses in the target universities so that curriculum and material revisers and developers, as well as policymakers, may draw gaps, focus areas and needs for future attempts of EAP oriented writing course development and alignment. Instructors of writing courses may as well draw important insights and information from this study to identify gaps in and adapt ways of improving their students' academic writing skills.

Journal on English as a Foreign Language, 10(1), 120-140

Copyright @ 2020 by JEFL, p-ISSN 2088-1657; e-ISSN 2502-6615 


\section{METHOD}

A mixed-methods design was chosen and employed for this study due to the nature of the research problem and the fundamental beliefs in and purpose of conducting this particular study. In fact, curriculum alignment and implementation in the context of educational institutions is the result of the intricate relationships of various educational and socio-cultural domains (Coolican, 2018). Thus, EAP alignment in terms of teaching writing for academic purposes rooted in such contexts is best investigated through a mixed-methods approach; mixing of qualitative methods with complementary quantitative data were used for the study.

Amhara National Regional State (ANRS) is one of the three largest regional states in Ethiopia. The region consisted of seven public universities which were categorized into first (Bahir Dar University and University of Gondar), second (Debre Birhan University, Wollo University, and Debre Markos University), and third (Debre Tabor University and Woldia University) generations based on their ascending chronological phase of establishment. Bahir Dar and Wollo Universities were selected from the first and second generations respectively using the lottery method whereas Debre Tabor University was selected on purpose due to the fact that this research was funded in, sponsored by and reported to the university.

The English Language and Literature Departments of the target universities delivered different writing courses for students of their own and across mainstream curricula. Since this study was set out to assess the alignment of EAP in EFL writing courses across mainstream curricula, its primary concern and sources of data were the common writing course syllabi and materials as well as the academic staff involved in developing and teaching them. Hence, instructors who are responsible for designing, preparing and teaching the existing writing courses were the key participants of the study.

Taking the nature, scope, and purpose of the research into careful consideration, the researchers employed purposive sampling techniques. In so doing, by using department heads as the source of information (i.e., snowball sampling), the researchers had first identified EFL instructors who were responsible for designing, preparing and teaching the existing common writing courses for further sampling. Then, due to the manageability of their total population size, all of the identified instructors, sixty-eight, were taken as sample informants (i.e., comprehensive sampling).

Journal on English as a Foreign Language, 10(1), 120-140

Copyright @ 2020 by JEFL, p-ISSN 2088-1657; e-ISSN 2502-6615 
In this study, questionnaires were administered to collect data from writing instructors in the target universities. The questionnaire consisted of closed-ended items (see Appendix). The questionnaire items focused on inquiring how academic writing genres were integrated into common writing courses, and what gaps teachers had observed in the alignment of EAP in their writing courses vis-à-vis development of their students' academic writing skills.

The content and face validity of the questionnaire items were first reviewed by two EFL educators at Debre Tabor University (DTU). On the basis of comments from these reviewers, the contents of the questionnaires were revised before they were ready to be tested via a pilot study. Various literature in research methods suggests that researchers are believed to benefit much from ascertaining the face validity of questionnaires by using some participants of their research for a pilot study (Gray, 2004). Hence, a pilot study involving participants in Debre Tabor University (DTU) was conducted before the actual administration of the questionnaires.

First-hand data were also gathered from a survey of the current writing course syllabuses and materials in the target universities; this was intended to investigate the extent to which EAP is compatibly incorporated in the existing EFL writing curricula, and how different academic writing genres are integrated in the writing courses. A review checklist was developed in light of the research questions as well as EAP material evaluation guidelines suggested by Rogers (2010). The check-list was piloted and scrutinized by ELT experts at DTU before being used for the reviews.

Semi-structured focus group discussions (FGDs) were conducted with the Curriculum and Materials Evaluation and Development Committee members in the ELL departments of the three target universities. The focus group discussions (FGDs) were mainly concerned with the curricular orientations and teacher mediation issues regarding EAP alignment in writing courses. The guiding items of the FGDs were scrutinized by independent TEFL scholars in DTU before the actual administration in order to ensure face and content validity.

A thematic approach was used to analyze and interpret qualitative data obtained from the syllabus and materials survey and open-ended questionnaire items. Complementary quantitative data obtained from closed-ended questionnaire items, on the other hand, were analyzed statistically using frequency, percentage and mean.

Journal on English as a Foreign Language, 10(1), 120-140

Copyright (C) 2020 by JEFL, p-ISSN 2088-1657; e-ISSN 2502-6615 


\section{FINDINGS}

Based on the research study questions, analyses were made. The analyses were initiated from the instructors' questionnaire, syllabus, and materials survey and focus-group discussions (FGDs). The data collected by the research tools were categorized, scrutinized and interpreted. Then, data of each research question was presented, and then the findings of related research studies that consolidated the findings of the current study were demonstrated.

To answer the first question, "How are writing courses distributed across mainstream curricula at the target universities?", syllabus and materials survey and focus-group discussions were conducted. Writing courses that are given across mainstream curricula - i.e., those courses that are correspondingly distributed across and shared by different departments - are widely referred to as common courses. In the present case, the existing distributions of common writing courses across mainstream curricula in the target universities are analyzed and discussed from two outlooks: pattern and manner of the distributions.

The reviews conducted on the existing university curricula revealed that all departments of all the target universities have incorporated Basic Writing Skills (course code: EnLa 1012) in their curricula. However, there are slight interdepartmental timetable variations. For instance, while most departments provide the course in the second semester of the first year of study, a few departments such as the Department of Tourism \& Hotel Management and Department of Civil Engineering provide the course in the first semester of the second year of study.

Still, some faculties, including those of technology and agriculture, provide an additional technical writing course - in majority cases, entitled Research and Technical Report Writing - despite variations in course name, code, content, and delivery among faculties. The research and technical report writing courses can be either faculty or department based, and, in most cases, provided for senior class students. Hence, the contents of the writing texts and activities in the course are often in line with the broad academic subject matters and discourses of the target students' study areas.

The problem that the FGD informants persistently raised in this regard was, however, biased course ownership and teacher assignment. According to the FGD informants, even though the course was meant to be (and should have

Journal on English as a Foreign Language, 10(1), 120-140

Copyright @ 2020 by JEFL, p-ISSN 2088-1657; e-ISSN 2502-6615 
been) taught by language teachers from the Department of English Language and Literature, if not jointly with host department teachers, the host departments 'illicitly' took the liberty of teaching it exclusively by their own teachers, who 'are not qualified' to teach language courses. An FGD 3 informant (IBR) from DTU further added that:

Even the Technical Report Writing course syllabus and modules are prepared only by host departments; they do not have any consultation and comments from the English language department.... In my view, host department teachers may be experts in the [subject-matter] content, but they do not have knowledge of teaching English and preparing [ELT] materials.

These claims were cross-checked against official teacher-to-course assignment documents from respective host faculties and found to be true.

Nevertheless, most of the departments in the faculties including Social Sciences, Humanities, and Behavioral Sciences did not have their own academic and/or technical or equivalent writing courses in their curricula, except 'Basic Writing Skills'. According to the FGD informants, as far as academic writing is concerned, students in these faculties are confined to, and perhaps rely only on, what they learn in the freshman 'Basic Writing Skills' course, which is not particularly designed for and aligned with their specific disciplinary content, discourse as well as learning needs.

To answer the second question, "To what extent are common writing courses compatibly aligned with the disciplinary content across host departments?", instructors' questionnaires and focus-group discussions were steered. The instructors' responses on the compatibility of writing courses with mainstream disciplines are shown in Table 1.

The data obtained from the questionnaires (Item 1 to 5) were first tallied and tabulated and were registered as the frequency that could show the number of respondents for each item. The mean score of each item was computed in line with the coding numerals. Hence, a higher mean score indicates the respondents' high acuity or frequent practice and vice-versa. Therefore, the analysis was done relating the computed percentage and mean values and the results ranged between mean scores 5 to 1 . The result of the computed aggregate mean value is 2.30 . This indicates that there was no compatibility of writing courses with mainstream disciplines.

Journal on English as a Foreign Language, 10(1), 120-140

Copyright (C) 2020 by JEFL, p-ISSN 2088-1657; e-ISSN 2502-6615 
Table 1. Instructors' responses on the compatibility of writing courses with mainstream

\begin{tabular}{|c|c|c|c|c|c|c|c|c|c|}
\hline \multirow{2}{*}{ No } & \multirow{2}{*}{ Item } & & \multicolumn{5}{|c|}{ Response } & \multirow{2}{*}{ Total } & \multirow{2}{*}{ Mean } \\
\hline & & & 5 & 4 & 3 & 2 & 1 & & \\
\hline \multirow[t]{2}{*}{1} & \multirow{2}{*}{$\begin{array}{l}\text { The course is designed for } \\
\text { the learners' particular field } \\
\text { of study. }\end{array}$} & $\mathrm{F}$ & 0 & 5 & 0 & 22 & 41 & 68 & 1.54 \\
\hline & & $\%$ & 0 & 7.4 & 0 & 32.4 & 60.2 & 100 & \\
\hline \multirow[t]{2}{*}{2} & \multirow{2}{*}{$\begin{array}{l}\text { The course clearly set high } \\
\text { expectations for the learners' } \\
\text { academic writing } \\
\text { competence. }\end{array}$} & $\mathrm{F}$ & 9 & 12 & 1 & 29 & 17 & 68 & 2.51 \\
\hline & & $\%$ & 13.2 & 17.6 & 1.5 & 42.7 & 25 & 100 & \\
\hline \multirow[t]{2}{*}{3} & \multirow{2}{*}{$\begin{array}{l}\text { The contents of model texts } \\
\text { are topically related to the } \\
\text { learners' field of study. }\end{array}$} & $\mathrm{F}$ & 6 & 15 & 0 & 29 & 18 & 68 & 2.44 \\
\hline & & $\%$ & 8.8 & 22.1 & 0 & 42.7 & 26.4 & 100 & \\
\hline \multirow[t]{2}{*}{4} & \multirow{2}{*}{$\begin{array}{l}\text { The writing tasks are } \\
\text { typically suited to the target } \\
\text { learners' field of study. }\end{array}$} & $\mathrm{F}$ & 9 & 15 & 5 & 20 & 19 & 68 & 2.63 \\
\hline & & $\%$ & 13.2 & 22.1 & 7.4 & 29.4 & 27.9 & 100 & \\
\hline \multirow[t]{2}{*}{5} & \multirow{2}{*}{$\begin{array}{l}\text { Either the syllabus or } \\
\text { material of the course guides } \\
\text { to adapt a range of academic } \\
\text { writing topics. }\end{array}$} & $\mathrm{F}$ & 7 & 11 & 2 & 30 & 18 & 68 & 2.40 \\
\hline & & $\%$ & 10.3 & 16.3 & 2.9 & 44.1 & 26.4 & 100 & \\
\hline
\end{tabular}

As explained in Table 1, majority of the instructor respondents either strongly disagreed $(60.2 \%)$ or disagreed $(32.4 \%)$ with the statement that the common writing course they teach (i.e., 'Basic Writing Skills') was specifically designed for their learners' particular field of study while the rest $7.4 \%$ agreed. This clearly indicates that the course is rather designed commonly for all departments, and therefore, its contents may not match the specific curricular content and disciplinary discourse of individual fields of study.

Similarly, regarding whether the objectives of the course clearly set high expectations for the learners' academic writing competence on a range of topics related to their mainstream discipline, $42.7 \%$ and $25 \%$ of the respondents respectively expressed disagreement and strong disagreement whereas the remaining $17.6 \%, 13.2 \%$, and $1.5 \%$ agreed, strongly agreed and were not sure respectively. This, in turn, shows that the objectives of the course clearly do not set high expectations for the learners' academic writing competence on a range of topics related to their mainstream discipline. 
In more specific terms, the third and fourth items, respectively, inquire whether the contents of model texts and writing tasks in the course were topically compatible with the learners' particular field of study. Hence, majority of the teacher respondents either disagreed (42.7\%) or strongly disagreed $(26.4 \%)$ against the compatibility of model texts; similarly, $29.4 \%$ and $27.9 \%$ respectively disagreed and strongly disagreed against the compatibility of model texts with the specific curricular contents of the target students' mainstream learning. Here, one can understand that the contents of model texts and writing tasks in the course were not deliberate to be topically compatible with the learners' particular field of study.

Last but not least, the teacher respondents were asked to rate their opinions about whether either the syllabus or the material of their course guides them to adapt a range of academic writing topics to their students' mainstream learning. Consequently, most of them (i.e., $44.1 \%$ who disagreed and $26.4 \%$ who strongly disagreed) responded negatively. It can be implied from the responses that neither the syllabus nor the material of their writing course guides them to adapt a range of academic writing topics to their students' mainstream learning.

In addition, the conducted reviews of 'Basic Writing Skills' course syllabus and materials showed comparable material preparation schemes in the three universities in spite of some differences in details and format. That is, the course is prepared and, therefore, provided as a common course across all university departments - for freshman students in most cases. Consequently, all students who take the course in each university learn with exactly the same modules regardless of their fields of study. Although there might be arbitrary relevance of texts with random fields of study, no deliberate attempt was indicated in the course syllabus and materials design to align contents of texts and tasks with the specific disciplinary content and discourse of each host department or faculty.

To answer the third question, "How effectively are academic writing genres incorporated in common writing courses vis-à-vis the respective disciplinary discourse of host departments?", instructors' questionnaires and syllabus and materials survey were shepherded. The instructors' responses to the incorporation of academic genres in writing courses are shown in Table 2.

Journal on English as a Foreign Language, 10(1), 120-140

Copyright ( 2020 by JEFL, p-ISSN 2088-1657; e-ISSN 2502-6615 
Table 2. Instructors' responses to the incorporation of academic genres in writing courses

\begin{tabular}{|c|c|c|c|c|c|c|c|c|c|}
\hline \multirow{2}{*}{ No } & \multirow{2}{*}{ Item } & & \multicolumn{5}{|c|}{ Response } & \multirow{2}{*}{ Total } & \multirow{2}{*}{ Mean } \\
\hline & & & 5 & 4 & 3 & 2 & 1 & & \\
\hline \multirow[t]{2}{*}{6} & The course objectives clearly & $\mathrm{F}$ & 8 & 15 & 4 & 28 & 13 & 68 & 2.70 \\
\hline & $\begin{array}{l}\text { set high expectations for the } \\
\text { learners' competence. }\end{array}$ & $\%$ & 11.8 & 22.1 & 5.9 & 41.1 & 19.1 & 100 & \\
\hline \multirow[t]{2}{*}{7} & The course incorporates & $\mathrm{F}$ & 18 & 26 & 3 & 14 & 7 & 68 & 3.50 \\
\hline & $\begin{array}{l}\text { different kinds of rhetorical } \\
\text { patterns. }\end{array}$ & $\%$ & 26.5 & 38.2 & 4.4 & 20.6 & 10.3 & 100 & \\
\hline \multirow[t]{2}{*}{8} & The course offers students & $\mathrm{F}$ & 10 & 16 & 1 & 29 & 12 & 68 & 2.80 \\
\hline & $\begin{array}{l}\text { with sufficient activities to } \\
\text { practice writing a wide } \\
\text { range of academic papers. }\end{array}$ & $\%$ & 14.7 & 23.5 & 1.5 & 42.6 & 17.7 & 100 & \\
\hline \multirow[t]{2}{*}{9} & Either the syllabus or & $\mathrm{F}$ & 6 & 10 & 3 & 28 & 21 & 68 & 2.30 \\
\hline & $\begin{array}{l}\text { material of the course } \\
\text { guides to adapt a range of } \\
\text { alternative genres. }\end{array}$ & $\%$ & 8.8 & 14.7 & 4.4 & 41.1 & 30.9 & 100 & \\
\hline
\end{tabular}

The data obtained from the questionnaires (Item 6 to 9) were first corresponded and tabularized and were registered as the frequency that could show the number of respondents for each item. The mean score of each item was computed in line with the coding numerals. Hence, a higher mean score indicates the respondents' high perspicacity or recurrent practice. Hence, the analysis was done relating the computed percentage and mean values and the results ranged between mean scores 5 to 1 . When this is explained in terms of mean, the computed aggregate mean value is 2.83 which indicates truncated incorporation of academic genres in writing courses.

As shown in Table 2, in response to whether the objectives of the common writing course clearly set high expectations for the learners' competence in writing a range of text types (genres) related to their mainstream learning, $41.1 \%$ and $19.1 \%$ of the respondents respectively express disagreement and strong disagreement whereas the remaining $22.1 \%, 11.8 \%$, and $5.9 \%$ agreed, strongly agreed and were not sure respectively. This, in turn, implies that the objectives of the course clearly do not clearly set high expectations for the learners' competence in writing a range of text types (genres) related to their mainstream disciplinary learning and discourse. 
For the second item in the table, however, majority of the teacher respondents either agreed $(38.2 \%)$ or strongly agreed $(26.5 \%)$ the common 'Basic Writing Skills' course incorporated the different kinds of rhetorical patterns such as narratives, descriptions, arguments, and expositions that learners may need for academic writing. Still, in the succeeding (fourth) item, contrasting responses were obtained regarding whether course offers students with sufficient activities to practice writing a wide range of academic papers (e.g., lab reports, surveys, term papers, etc.) that they are expected to perform in their mainstream learning, to which $42.6 \%$ and $17.6 \%$ respondents disagreed and strongly disagreed respectively. Hence, one can deduce that even if students learn different types of text patterns, they lack sufficient practice to apply these patterns in writing the different academic papers (e.g., lab reports, surveys, term papers, etc.) that they may be required to do in their respective mainstream learning.

In the last item, the teacher respondents were asked to rate their opinions about whether either the syllabus or material of their course guides them to adapt a range of alternative genres in accordance with their students' disciplinary discourse. Consequently, most of them (i.e., $41.1 \%$ who disagreed and $30.9 \%$ who strongly disagreed) responded disapprovingly. The responses imply that neither the syllabus nor the material of the common writing course guides teachers to adapt a range of alternative genres in accordance with their students' disciplinary discourse.

According to the syllabus and material reviews, the chapters and topics of 'Basic Writing Skills' courses in all the target universities are organized and graded from simple to more complex levels of writing despite some variations in the substance, detail, and assortment of notes and tasks among materials. The course is broadly divided into three consecutive parts or levels of writing: Sentence Writing, Paragraph Writing, and Essay Writing.

In terms of genres, one of the noteworthy strengths of the course is that different types of texts at a sentence, paragraph and essay levels are presented, discussed and exercised vis-à-vis their structures and purposes in written communication. Sentences are classified based on both their function (i.e., declarative, interrogative, exclamatory, and imperative) and structure (i.e., simple, compound, complex, and compound-complex). Paragraphs and essays, on the other hand, are categorized according to their communicative functions (i.e., expository, descriptive, narrative, and argumentative). Accordingly, different sample texts are provided followed by activities for students.

Journal on English as a Foreign Language, 10(1), 120-140

Copyright (C) 2020 by JEFL, p-ISSN 2088-1657; e-ISSN 2502-6615 
In Tables 3 and 4, it shows the sample texts extracted from 'Basic Writing Skills' modules in the target universities to show how different text types (i.e., genres) are presented at different levels of writing.

Table 3. Sample text in sentence level writing

\begin{tabular}{|c|c|}
\hline \multicolumn{2}{|c|}{ Sentence level writing } \\
\hline Declarative sentences are sentences & Examples: \\
\hline which tell us about any kind of & - Hailu is a doctor. \\
\hline information in a statement form. A & - Gambling is an illegal activity. \\
\hline $\begin{array}{l}\text { declarative sentence always ends with a } \\
\text { period (.). }\end{array}$ & - I always think of my profession. \\
\hline
\end{tabular}

Table 3 shows the sample texts in sentence level writing extracted from 'Basic Writing Skills' Module published by the Department of English Language and Literature of Debre Tabor University (DTU) (2017, p. 14). Such explanation and example in Table 3 are typically followed by tasks instructing students to identify types of given individual sentences.

Table 4. Sample text in paragraph and essay level writing

\begin{tabular}{ll}
\hline \multicolumn{3}{c}{ Paragraph and essay level writing } \\
\hline $\begin{array}{l}\text { Description is a verbal picture of a person, } \\
\text { place, or thing. It is the kind of writing which }\end{array}$ & And to all these familiar sounds of birds, cars, \\
attempts to appeal to the reader's sense, & people, pet animals, ... chirps, engine-noise, \\
recreating for him the author's original & chatter, barks,... to all the sharp and thrilling \\
impression of the subject being described. It & odors of the trains -the smell of cinders, acrid \\
is very much concerned with sensory & smoke, of musty, rusty freight cars, the clean \\
impressions (sight, sound, smell, taste, & pine-board of crated produce, and the smells of \\
touch). A description can be objective or & fresh stored food-oranges, coffee, tangerines and \\
impressionistic. The description rarely & bacon, ham and flour and beef-there would be \\
appears alone in modern writing. It is most & added now, with an unforgettable magic and \\
often used with narration. ... & familiarity, all the strange sounds and smells of \\
& the coming circus... \\
\hline
\end{tabular}

Table 4 shows the sample texts in paragraph and essay level writing extracted from Basic Writing Skills Module published by the Department of English Language and Literature of Bahirdar University (BDU) (2016, p. 111). Such detailed explanations are normally followed by example texts in Table 4.

Subsequent activities for students include identifying types of given texts and writing own paragraphs and essays having different genres. Topics for extended writing tasks are given more often than not along with the type(s) of

Journal on English as a Foreign Language, 10(1), 120-140

Copyright (C) 2020 by JEFL, p-ISSN 2088-1657; e-ISSN 2502-6615 
text(s) the students are expected to produce; hence, students may learn to compare and contrast different topic areas with corresponding genres.

Accumulating the research findings one can comprehend that all learners in taking the common course 'Basic Writing Skills' in each university learn with the same syllabus and material regardless of their fields of study. Therefore, the contents of common writing courses at public universities in ANRS lack deliberate alignment and compatibility with the specific disciplinary content and written discourse of target students' particular fields of study even if there might be inadvertent thematic relevance between random texts and fields of study. And, this problem involves the poor alignment of writing courses with the target students' mainstream discipline (i.e., learning and discourse) both in terms of content and genre.

\section{DISCUSSION}

The first question in the study is sought to determine the distribution of writing courses across mainstream departments. Results revealed that there existed a comparable horizontal (cross-department) distribution pattern of common writing courses among the three universities. However, there are considerable professionalism issues in assigning teachers particularly to teach research and technical report writing courses. That is, writing courses (Basic Writing Skills, Research, and Technical Report Writing) were being exclusively taught by host department teachers who are assumed to have subject matter (content) expertise regardless of their lack of qualification and expertise in ELT, if not also in the language itself (Fareed et al., 2016; Hyland \& Hamp-Lyons, 2002; Kruse, 2007; Leung, 2008; Nasser, 2018; Wahyuni \& Umam, 2017). English for academic purposes refers to language research and instruction that focuses on the specific needs and practices of particular groups in academic contexts. It means grounding instruction in an understanding of the cognitive, social, and linguistic demands of specific academic disciplines.

The second research question scrutinized the compatibility of common writing courses with target disciplinary content. It was implied that all learners in taking the common course 'Basic Writing Skills' in each university learnt with the same syllabus and material regardless of their fields of study. Therefore, the contents of common writing courses at tertiary levels were not accordingly aligned and compatible with the specific disciplinary content and written discourse of target students' particular fields of study although there may be arbitrary relevance between texts and thematic areas of random fields of study. There was no compatibility of common writing courses with target

Journal on English as a Foreign Language, 10(1), 120-140

Copyright ( 2020 by JEFL, p-ISSN 2088-1657; e-ISSN 2502-6615 
disciplinary content; this is consistent with Ariyanti and Fitriana (2017), Cahyono et al. (2016), Husin and Nurbayani (2017), Rogers (2010), and Thesen (2013).

It has recurrently been appealed that the development of language and language-related skills is an important part of learning across mainstream curricula. An obvious and general reason for such claims is the assumption that language is the medium with/hrough which knowledge or content is transmitted. Hence, the argument, in this case, is that competency in using language and associated skills contribute a great deal to enhance learning. Moreover, the current applied linguistic and language teaching theories tend to advocate an integrated approach to language teaching and language curriculum design that language and content are complementary rather than distinctive to each other (Cahyono et al., 2016; Scholtz, 2016).

The third question in this study is pursued to determine the incorporation of academic genres in the writing courses. Results publicized that two major limitations were detected in the 'Basic Writing Skills' course materials with respect to the incorporation of academic writing genres. Firstly, the incorporated text genres are not clearly identified, explicitly discussed and deliberately exercised in terms of their function, accordance and use in particular academic writing settings. Secondly, since the course has a 'common course' status (i.e., given across all departments), the different text genres are not respectively specified for and aligned with the particular - and often unique - curricular content, academic discourse and learning needs of individual target departments.

This idea is in line with Cahyono et al. (2016), Husin and Nurbayani (2017), Jacobs (2013), Nasser (2018), and Weideman (2013). Many studies in academic writing at higher education contexts show that writing instruction must consider, among other things, the learning needs of students across disciplines and associated discourse genres (Bailey, 2009). This claim is strongly supported by Belkhir and Benyelles (2017), Brown (2000), and Fareed et al. (2016). It is, nonetheless, a peculiar problem for many practitioners.

Taken together, these discussions suggest that incompatibility of writing courses with the mainstream (curricular) content and discourse due to lack of effective EAP curriculum alignment will end up profoundly hindering students' academic writing development and competence that they inevitably need to succeed in their learning.

Journal on English as a Foreign Language, 10(1), 120-140

Copyright @ 2020 by JEFL, p-ISSN 2088-1657; e-ISSN 2502-6615 


\section{CONCLUSION}

This study aimed at assessing the prevailing alignment of EAP in EFL writing courses vis-à-vis the development of the academic writing skills of students. The results of the study revealed that there existed a comparable horizontal (cross-department) distribution pattern of common writing courses among the three universities. All departments of all the target universities have incorporated Basic Writing Skills (course code: EnLa 1012) in their curricula. Still, some faculties, including those of technology and agriculture, provide an additional technical writing course - in majority cases, entitled: Research and Technical Report Writing - despite variations in course name, code, content, and delivery among faculties. Based on the results of the study, all learners in taking the common course 'Basic Writing Skills' in each university learnt with the same syllabus and material regardless of their fields of study. Therefore, the contents of common writing courses at public universities in ANRS lack deliberate alignment and compatibility with the specific disciplinary content and written discourse of target students' particular fields of study even if there might be inadvertent thematic relevance between random texts and fields of study. And, this problem involves the poor alignment of writing courses with the target students' mainstream discipline (i.e., learning and discourse) both in terms of content and genre. Since higher education students essentially need critical understanding, extensive practice and high competence of EAP writing, the universities should develop and provide a distinct Academic Writing course in particular alignment with learners' mainstream learning and disciplinary discourse.

\section{REFERENCES}

Abebe, W. Y. (2013). Fostering academic genre knowledge of EFL learners throgh content and language integrated learning (CLIL). International Journal of Society, Culture E Language, 1(2), 133-144.

Amogne, D. (2013). Enhancing students writing skills through the genre approach. International Journal of English and Literature, 4(5), 242-248. https://doi.org/10.5897 /JEL2013.0421

Ariyanti, A., \& Fitriana, R. (2017). EFL students' difficulties and needs in essay writing. In Proceedings of the International Conference on Teacher Training and Education 2017 (ICTTE 2017). Advances in Social Science, Education and Humanities Research (ASSEHR), volume 158 (pp. 111-121). Atlantis Press. https://doi.org/10.2991/1́ctte-17.2017.4

Journal on English as a Foreign Language, 10(1), 120-140

Copyright @ 2020 by JEFL, p-ISSN 2088-1657; e-ISSN 2502-6615 
Bailey, S. (2009). Academic writing: A handbook for international students (2 ${ }^{\text {nd }}$ ed., reprinted). Routledge.

Belcher, D. (2009). What ESP is and can be: An introduction. Michigan ELT.

Belkhir, A., \& Benyelles, R. (2017). Identifying EFL learners essay writing difficulties and sources: A move towards solution the Case of second year EFL learners at Tlemcen University. International Journal of Learning, Teaching and Educational Research, 16(6), 80-88. Retrieved from https:/www.ijlter.org/index.php/ijlter/article $/$ iew 915

Brown. H. D. (2000). Teaching by principles: An interactive approach to language pedagogy ( $2^{\text {nd }}$ ed.). New York: Pearson-Longman.

Cahyono, B. Y., Mukminatien, N., \& Amrina, R. (2016). Indonesian students' writing proficiency and their ability in using complex sentences. International Journal on Studies in English Language and Literature (IJSELL), 4(9), 22-32. http://dx.doi.org/10.20431/2347-3134.0409004

Coolican, H. (2018). Research Methods and Statistics in Psychology. London: Hoddler and Stoughton Publisher.

Department of English Language and Literature. (2016). Basic writing skills module. Bahirdar: Bahirdar University (BDU).

Department of English Language and Literature. (2017). Basic writing skills module. Debre Tabor: Debre Tabor University (DTU).

Fareed, M., Ashraf, A., \& Bilal, M. (2016). ESL learners' writing skills: Problems, factors and suggestions. Journal of Education $\mathcal{E}$ Social Sciences, 4(2), 83-94. https://doi.org/10.20547/ßess0421604201

Graham, S., \& Hebert, M. (2010). Writing to read: Evidence for how writing can improve reading. New York: Carnegie Corporation.

Gray, D. E. (2004). Doing research in the real world. New York: Sage Publications.

Husin, M. S., \& Nurbayani, E. (2017). The ability of Indonesian EFL learners in writing academic papers. Dinamika Ilmu, 17(2), 237-250. https://doi.org/10.21093/di.v17i2.725

Hyland, K. (2016). Methods and methodologies in second language writing research. System, 59, 116-125. https://doi.org/10.1016/.system.2016.05.002

Hyland, K., \& Hamp-Lyons, L. (2002). EAP: Issues and directions. Journal of English for Academic Purposes, 1(1), 1-12. https://doi.org/10.1016/S14751585(02)00002-4

Jacobs, C. (2013). Academic literacies and the question of knowledge. Journal for Language Teaching, 47(2), 127-140. https://doi.org/10.4314/jlt.v47i2.7

Kooshafar, M., Youhanaee, M., \& Amirian, Z. (2012). The effect of Dictogloss technique on learners' writing improvement in terms of writing coherent

Journal on English as a Foreign Language, 10(1), 120-140

Copyright @ 2020 by JEFL, p-ISSN 2088-1657; e-ISSN 2502-6615 
texts. Journal of Language Teaching and Research, 3(4), 716-721. https://doi.org/10.4304 Øltr.3.4.716-721

Kruse, O. (2007). The origins of writing in the disciplines: Traditions of seminar writing and the Humboldtian ideal of the research university. Written Communication, 23(3), 331-352. Retrieved from https://eric.ed.gov /?id=EJ738413

Leung, C. (2008). Second language academic literacies: Converging understandings. In B. V. Street \& N. H. Hornberger (Eds.), Encyclopedia of Language and Education, 2nd Edition, Volume 2: Literacy, (pp. 145-161). Springer Science+Business Media LLC.

Mardijono, J. J. (2003). Indonesian EFL advanced learners' grammatical errors. K@ta Lama, 5(1), 91-120. https://doi.org/10.9744/kata.5.1.91-120

Mol, H., \& Tin, T. B. (2008). EAP materials in Australia and New Zealand. In B. Tomlinson (Ed.), English Language Learning Materials: A Critical Review (pp. 74-99). London: Continuum International Publishing Group.

Myles, J. (2002). Second language writing and research: The writing process and error analysis in student texts. TESL - EJ, 6(2), 1-20. Retrieved from http:/tesl-ej.org/ej22/a1.html

Nasser, S. (2018). Iraqi EFL students' difficulties in writing composition: An experimental study (University of Baghdad). International Journal of English Linguistics, 9(1), 178-184. https://doi.org/10.5539/ijel.v9n1p178

Neville, D. (2007). The complete guide to referencing and avoiding plagiarism. Berkshire: Open University Press.

Otte, G. \& Mlynarczyk. (2010). Basic writing. West Lafayette, Indiana: Parlor Press LLC.

Ožarska, M. (2008). Some suggestions for academic writing instruction at English teacher training colleges. English Teaching Forum, 46(1), 22-29.

Puhr, K. M. (2007). English language and composition: Teacher's guide. St. Louis, Missouri: College Board Advanced Placement Program.

Richard, J. C. (2006). Communicative language teaching in China. Cambridge: CUP.

Rogers, P. (2010). The contribution of North American longitudinal studies of writing in higher education to our understanding of writing development. In C. Bazerman, R. Krut, K. Lundsford, S. McLeod, S. Null, P. Rogers, \& A. Stansell (Eds.), Traditions of Writing Research (pp. 365-377). New York: Routledge.

Sanu, L. O. (2016). The EFL students' narrative paragraph writing of the second semester students of State Institute of Islamic Studies (IAIN) Samarinda: A syntactic analysis. Script Journal: Journal of Linguistic and English Teaching, 1(1), 36-45. https://doi.org/10.24903/sj.v1i1.15

Journal on English as a Foreign Language, 10(1), 120-140

Copyright (C) 2020 by JEFL, p-ISSN 2088-1657; e-ISSN 2502-6615 
Scholtz, D. (2016). Improving writing practices of students' academic literacy development. Journal for Language Teaching, 50(2), 37-55. https://doi.org/10.4314 „ltt.v50i2.2

Tefera, K. (2003). A study of students' academic writing in response to instructors' expectations at AAU: Four departments in focus (Unpublished Thesis), Addis Ababa University. Retrieved from http://etd.aau.edu.et/handle/123456789/2161

Thesen, L. (2013). Risk in postgraduate writing: Voice, discourse and edgework. Critical Studies in Teaching and Learning, 1(1), 103-122.

Wahyuni, S., \& Umam, M. K. (2017). An analysis on writing anxiety of Indonesian EFL college learners. JEELS (Journal of English Education and Linguistics Studies), 4(1), 105-128. https://doi.org/10.30762 /jeels.v4i1.333

Weideman, A. (2013). Academic literacy interventions: What are we not yet doing, or not yet doing right? Journal for Language Teaching, 47(2), 11-24. https://doi.org/10.4314 亿lt.v47i2.1

Workie, M. B. (2019). A Probe on the Dares of teaching speaking skills in EFL classrooms: Secondary schools in focus, North Western Ethiopia. International Journal of English Literature and Culture, 7(8), 246-253. https://doi.org/10.14662/JELC2019.210

Yazdani, S. (2018). Syntactic complexity in Iranian learners' English writing and speaking. Journal on English as a Foreign Language, 8(1), 75-96. https://doi.org/10.23971 hefl.v8i1.718

\section{Authors' Brief CV}

Melaku Bayu Workie is a lecturer in the Department of English Language and Literature, Debre Tabor University, Ethiopia. He obtained his MA degree in TEFL from Addis Ababa University (2016) and B.Ed degree in English Language and Literature from Ambo University (2009). He desires to study his Ph.D. in Applied Linguistics.

Zelealem Shitahun Haregu is a Ph.D. candidate in TEFL in the Department of English Language and Literature, Bahir Dar University, Ethiopia. He obtained his M.Ed. degree in Teaching English as a Foreign Language (TEFL) and B.Ed. degree in English Teaching from Bahir Dar University in 2015, 2009 respectively. 


\section{Appendix: Questionnaire for instructors of common EFL writing courses}

\section{Introduction}

This questionnaire is intended for a common EFL writing course. Please note that responses obtained through this questionnaire will NOT be used, exposed and/or altered devoid of the prior consent of the respondent, and respondent's identity and any other confidential information will NOT be revealed to third parties by any means. Moreover, given responses will be employed ONLY for the aforementioned research purpose.

This questionnaire consists of both closed- and open-ended items. Please read all the items carefully and provide honest responses accordingly. To respond, put $[\sqrt{ }]$ mark in the boxes of your choice for closed-ended items, and respond briefly in your own words for the open-ended item.

\section{Background Information}

1. The university you teach in (Please specify).

2. The writing course(s) you teach (Please specify).

\section{Questions}

Response Key:

5=Strongly Agree $\quad 4=$ Agree $\quad 3=$ Not sure $\quad 2=$ Disagree $1=$ Strongly Disagree

\begin{tabular}{|c|c|c|c|c|c|c|}
\hline \multirow{2}{*}{ No } & \multirow{2}{*}{ Item } & \multicolumn{5}{|c|}{ Responses } \\
\hline & & 5 & 4 & 3 & 2 & 1 \\
\hline 1 & $\begin{array}{l}\text { Items related to compatibility of language with } \\
\text { disciplinary content in writing courses }\end{array}$ & & & & & \\
\hline 1.1 & $\begin{array}{l}\text { The course you teach is specifically } \\
\text { designed for your learners' particular field } \\
\text { of study rather than for all or multiple } \\
\text { departments in general. }\end{array}$ & & & & & \\
\hline 1.2 & $\begin{array}{l}\text { The objectives of your writing course } \\
\text { clearly set high expectations for the } \\
\text { learners' academic writing competence on } \\
\text { a range of topics related to their } \\
\text { mainstream discipline. }\end{array}$ & & & & & \\
\hline 1.3 & $\begin{array}{l}\text { The contents of model texts in your course } \\
\text { are topically related to the learners' field of } \\
\text { study. }\end{array}$ & & & & & \\
\hline 1.4 & $\begin{array}{l}\text { The writing tasks in your course are } \\
\text { typically suited to the target learners' field } \\
\text { of study. }\end{array}$ & & & & & \\
\hline
\end{tabular}

Journal on English as a Foreign Language, 10(1), 120-140

Copyright (C) 2020 by JEFL, p-ISSN 2088-1657; e-ISSN 2502-6615 


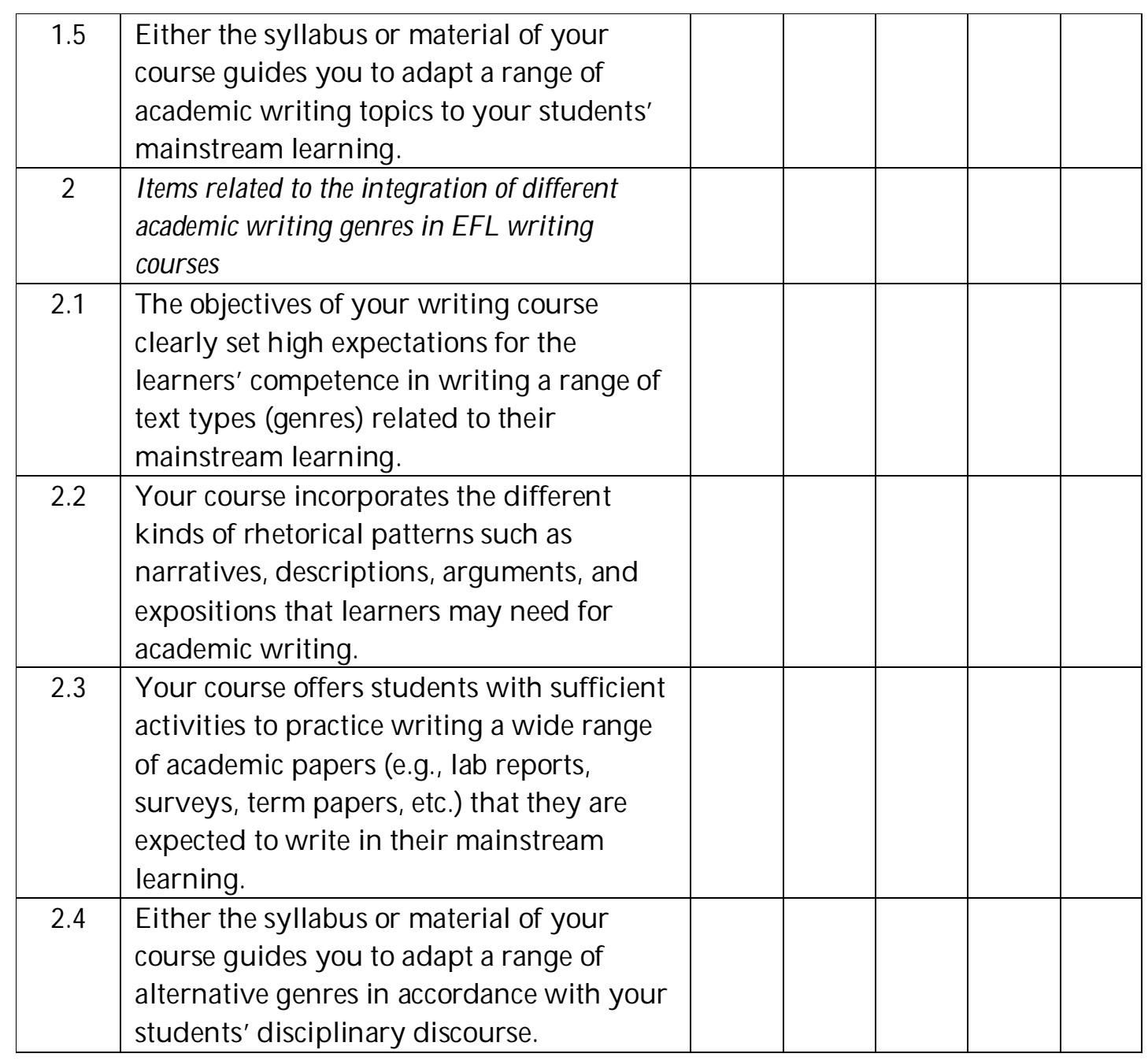

THANK YOU

Journal on English as a Foreign Language, 10(1), 120-140

Copyright ( 2020 by JEFL, p-ISSN 2088-1657; e-ISSN 2502-6615 